\title{
ÚJ VONÁSOK A BARANYA MEGYEI TERÜLETFEJLESZTÉSI KONCEPCIÓBAN ${ }^{1}$
}

(New Features of the Development Strategy for Baranya County)

\author{
HRUBI LÁSZLÓ
}

\section{Elözmények}

A Dél-Dunántúlon 1992-ben vette kezdetét a régióra (Baranya, Somogy, Tolna és Zala megyékre) vonatkozó fejlesztési tervezés, amelyet a négy megye és néhány egyéb alapító által létrehozott regionális fejlesztési alapítvány indított el. Ekkorra készült el a területfejlesztési törvény első teljesnek tekinthető tervezete, amely alapelveiben, megközelítési módjában az 1996-ban elfogadott változattól kevésbé különbözött. A helyi kezdeményezésre elindult regionális koncepcióalkotás e törvénytervezet szellemét, logikáját, normáit vette alapul, kiegészítve azzal a határozott törekvéssel, hogy az Európai Unióban bevett gyakorlat szerint készített ottani regionális fejlesztési dokumentumokkal rokon tervfajta készüljön. A kitekintés során olyan nyugat-európai régiókat kerestünk, amelyek nagyságukban, karakterisztikájukban hasonlíthatók a vizsgált térséghez $\{\mathrm{A}$ vizsgálatba az ily módon figyelembe vett régiók: Alsó-Normandia (Franciaország), Friuli-Venezia-Giulia (Olaszország), Asturia (Spanyolország), Közép-Makedónia (Görögország), Tübingen (Németország) és Ličge (Belgium)\}, és ezek fejlesztési tervei - valamint az EU dokumentumai - alapján körvonalaztuk a koncepcióépítés tartalmi-módszertani normáit. A legfóbb új vonásai e koncepciónak az alábbiak voltak:

- gazdaságfejlesztési stratégiai orientáció;

- az „eurokonform” regionális fejlesztési tervforma közelítése;

- mivel nem álltak rendelkezésre a gazdasági szervezetek fejlesztési tervei, primer adatfelvétellel szondáztuk a fejlesztési lehetőségeikre, jövőképükre vonatkozó becslésüket, továbbá egy külföldi céget bíztunk meg a releváns dél-dunántúli ágazatok, alágazatok európai piaci trendjeinek és a magyar részvételnek a jellemzésére, valamint a konjunkturális kilátások, és az azokhoz kapcsolható magyar lehetőségek karakterizálására;

- széles közbenső egyeztetési mechanizmus.

A régió koncepciója - többszöri átdolgozással - 1996 elején vált a megfelelő döntésekkel jóváhagyott tervdokumentummá. A tervfolyamat folytatása 1998 elején kezdődik, feladata a koncepcióban vázolt 13 prioritás közül hat elem programozása.

Az előzmények tekintetében a második mozzanat Pécs város 1996-ban elfogadott városfejlesztési koncepciója, amely minden tekintetben a regionális koncepcióval összhangban, de részletességében, a koncepció tartalmát (ebben már a prioritásokon túl a lehetséges programok köre is szerepelt, továbbá a városfejlesztés föbb rendezési típusú intézkedéseit is számba vette településrészenkénti bontásban, stb.), valamint a tervezés társadalmasítását (a javaslatot a város szellemi elitjét nagyrészt 
tömörítő intézmények kutatási konzorciuma készítette el az MTA RKK DTI irányításával) tekintve, azt meghaladva készült el.

A harmadik fontos elözmény a kezdetben Nemzeti, majd Országos Területfejlesztési Koncepció, amelynek (az általunk készített) tervezete a Phare keretében folytatott kutatásokra támaszkodva eleve az EU elveire és normáira alapozó dokumentumként készült el 1996 elején.

Összefoglalóan, Baranya megye fejlesztési koncepciója a tervelőzményeket tekintve viszonylag kedvezö alapra épült:

- az 1992 óta folyó dél-dunántúli regionális stratégiaépítés tartalmi, elvi és módszertani szempontból is előkészítette a megyei koncepció kidolgozását;

- elkészült és elfogadták Pécs városfejlesztési koncepcióját, amely a megközelités módja, a módszere és a tartalmi felépítése terén követte a regionális koncepciót, és jó illeszkedést kínált a megyei koncepcióhoz (azon túl is, hogy Baranyában minden fontosabb vonatkozásban Pécs súlya nagyobb, mint az országon belül a fövárosé);

- formálódott az Országos Területfejlesztési Koncepció, az elkészült változatok alapján valószinu็síthető volt a prioritások és a Baranyát is érintő fớbb programok köre.

Mindezek ellenére azonban az elözmények korántsem jelentettek optimális tervezési alapot. Egyebek mellett:

- a legnagyobb gondot az okozta, hogy hiányoztak a - a megyei koncepcióban elvileg rendkívül fontos szerepet játszó - kistérségi fejlesztési tervek (a jobbik esetben időben egybetolódva indult meg a kidolgozásuk, ezért csak néhány törekvés, elképzelés lehetett a megyei tervezés bázisa);

- nem építkezhetett a koncepcióalkotás meglevő vagy aktuális helyi-térségi ,ágazati” programokra sem (a területfejlesztési koncepció későbbi vitáiban egyébként kiderült, hogy ezek mintegy teljes körü pótlását is a megyei koncepciótól várták);

- semmilyen forrásból nem volt mód a gazdasági szervezetrendszer fejlesztési törekvéseinek, preferenciáinak a megbízható áttekintésére.

Az alulról építkező, partnerségre támaszkodó stratégiaépítés tehát a koncepció kidolgozása során szükségképpen ,helyettesítő eljárásokra” kényszerült.

\section{Alapelvek}

Az alulról építkezés (számolva természetesen a „felülröl illeszkedés” követelményeivel is), valamint az együttmüködésre és összehangolt (társfinanszírozott) fejlesztésekre alapozó stratégia követelménye határozta meg az első alapelvet.

Elöször is, ez a tervezési folyamat lehető legteljesebb „társadalmasítását” igényelte. A koncepció szakmai megalapozását (a Pécs városi koncepció esetében „megtanult" módon) a megye szellemi erőforrásait nagyjából összefogó - és a fejlödésben potenciálisan a legnagyobb humán tökét jelentő - helyi intézmények alkalmi konzorciuma végezte, rendszeres konzultációk és egyeztető megbeszélések beiktatásával. Ez utóbbiak szolgálták az alulról építkezés és a partnerség fent említett ,helyettesítö eljárásait” is. Céljuk a különböző érdekcsoportok, körök igényeinek „ex ante" tervezési számbavétele és egyeztetése, még akkor is, ha azok 
formálisan nem voltak döntések. A koncepció elfogadásáig összesen 38 ilyen tárgyalásra került sor. A legfontosabb konzultációs partnerek a kistérségek településközi együttmüködési formációi voltak. Ebböl adódóan - más lehetöségünk nemigen volt - a koncepcióalkotásban minden törekvésünk ellenére egy kissé túlsúlyos lett az önkormányzati-közösségi szféra részvétele. A kamarák - ebben az idöben - még nem voltak felkészülve a fejlesztési partneri szerepre, a szakmaitársadalmi szervezetek (civil szerveződések) közös véleményalkotása és képviselete pedig ,akadozott”.

Másodszor, értékelni és minősíteni kellett a megye egészét vagy egy részét érintö hatályos koncepciókat, terveket, fejlesztéseket, amelyeket - az autonóm döntéshozás miatt - tiszteletben kellett tartani és a megyei fejlesztési stratégiába - ha annak céljaival nem volt ellentétes - be kellett építeni. Ide sorolhatóak a fentebb előzményként emlitett tervdokumentumok. (Például a regionális koncepció 13 prioritása közül 12 érinti Baranyát, ezek részletesebb „címzése” elkerülhetetlen volt; Pécs város - a kifejezetten belsö, településfejlesztési rendeltetésü intézkedéseken felüli - fejlesztési programjainak átvétele már csak a város megyén belüli súlya és a térségi kihatások miatt is indokolt volt. Könnyebbséget jelentett az, hogy ezek rendre kötödnek a regionális koncepcióhoz is.).

Ezen a ponton léphetünk át $a$ második alapelvhez, ez pedig a területfejlesztési koncepció funkciója, küldetése. A területfejlesztési koncepció alapfunkciója az, hogy megteremtse a fejlesztésben érdekeltek és érintettek egyezségét a fejlesztési célok és az azok eléréséhez szükséges lépések, utak (prioritások) terén, és ez az érdekeltségi alapú konszenzus szilárd és viszonylag tartós fejlesztési bázis legyen. Ennek érdekében a megyei fejlesztési koncepció tartalmi tekintetben három meghatározó mozzanatra épül:

- mérlegelés és minősités után dönt a „felsöbb szintü” tervek, célok, programok saját fejlesztési céllá, programmá tételéröl és beépitéséröl (a fejlett országok tervezési gyakorlata ezt nem tekinti pusztán formális elemnek, és a magyar gyakorlatban is - a decentralizáció elörehaladtával egyre érdemibb döntési pont lesz);

- állást foglal a megye egészét vagy több körzetét érintő úgynevezett saját fejlesztési célokról és programokról, amelyek menedzselése megyei szintü feladat;

- meghatározza azt a fejlesztési kört, amelyet az alulról jövő (például kistérségi, települési, vállalkozói, stb.) kezdeményezésekből képes és kész a megyei szintü érdekekkel és a rendelkezésre álló vagy tervezhetö forrásokkal összhangban - befogadni, a prioritásokba beilleszteni és támogatni.

Az egyes szintek fejlesztési tervei között nincs „tervhierarchia”, következésképpen minden szint fejlesztési dokumentumánál nélkülözhetetlen elem a kompetens közősség döntése más, kapcsolódó szintek terveinek elfogadásáról, az abban való tevőleges részvételröl. Ez persze azt is jelenti, hogy „alulról” sincs automatikus beszámítás. Ma még kevésbé, de a jövöben nyilvánvalóan egyre többször előfordulhat, hogy bizonyos kistérségi célok nem válnak egyben megyei koncepcionális elemmé is.

$A$ harmadik alapelv a területfejlesztési koncepció épitkezésének módszertana. Feltett szándék volt, hogy a megyei koncepció az Európai Unióban általánossá vált 
úgynevezett „single programming document" típusú terv legyen. Ez a tervdokumentum leegyszerüsítve magába foglalja a hazai gyakorlat szerinti, szükebben vett koncepciót, a megvalósítás szabályozott útjának a kijelölését, valamint az ellenőrzés, értékelés bizonyos értelemben garanciális mozzanatát is. Az alulról építkezés bázisának hiánya egyelöre meggátolta az alapelv teljes érvényesitését, hisz a programok konkrét projektjeinek "tervszámai” vagy a forrásszükséglet az adott tervezési körülmények között meghatározhatatlan volt. A lehetöségek egy átmeneti tervfajtát eredményeztek, amely tartalmában mindenképpen meghaladta a koncepció kereteit, elveiben a single programming document típusú tervet adta, gyakorlatilag azonban csak elökészítette, de nem tette nélkülözhetövé a következö tervezési fázist, a programozást. A megoldás ellenére a korábbi fejlesztési dokumentumokhoz képest sokkalta egyértelmübbé vált a koncepció végrehajtásának és a fejlesztési támogatások, a forrásfelhasználás hatásosságának az ellenörizhetősége.

\section{Megközelitési mód}

A megyei területfejlesztési koncepció sem megközelítési módjában, sem tartalmában nem a megye fejlesztési terve, a kategória hagyományos értelmében. A megkőzelítési mód ebben a tekintetben négy sajátos mozzanatot jelentett:

- A területfejlesztési koncepciót határozott gazdaságfejlesztési orientáció jellemzi, minden tervelem ennek rendelödik alá.

- Következésképpen az infrastruktúra-fejlesztés csak olyan mértékben és körben jelenhet meg, amennyiben komparativ elöny vagy gazdaságfejlesztési korlát, illetöleg a fenntartható fejlődés környezeti elvét tekintve problématerület.

- Baranya megye aprófalvas jellegéből, valamint az ebböl is adódó helyenkénti tartós elmaradottságból (amióta a magyar területfejlesztési politikában ez a besorolás létezik, azóta Baranya déli és nyugati része valamilyen települési körrel mindig szerepelt az elhatárolt területek sorában) következően számottevő körben a területfejlesztésnek bizonyos, jellemzöen szociális célokat követö intézkedésekre is vállalkoznia kellett, mivel nálunk nincs egységes területi szociális fejlesztési alap (a kiegyenlítési célelöirányzat decentralizált része legfeljebb csak részben ilyen). Elkerülhetetlen volt, hogy a gazdaságfejlesztési megközelítési módot némileg megsértve a humán eröforrások fejlesztése, valamint a településrendszer müködőképességének javítása, vidékfejlesztés címü prioritásokba szociális természetŭ programok, alprogramok is beépüljenek.

- A területfejlesztési koncepció a közvetlen és bizonyítható térségi hatású elemeket foglalja magába, és ezektöl meg kell különböztetni az - esetleg térségi „álruhába" bújtatott - egyedi településfejlesztési törekvéseket. Ez a hazai gyakorlatban az egyik legkényesebb területfejlesztési tervezési pont: nagy a veszélye annak, hogy a területfejlesztés az alulról jövő nyomás miatt a településfejlesztés saját forrásainak szükülése miatt annak kiegészitö rendszerévé váljon, elsösorban lokális érdekeket szolgáljon (a folyamatot egyébként az is gerjeszti, hogy a megyei decentralizált források egyik eleme az úgynevezett kiegyenlitési célelöirányzat, amely az eltérö funkció ellenére ugyanazt az intézményesült rendszert használja, mint a területfejlesztési célelöirányzat); 
- A területfejlesztési koncepció nem vállalhatja át az adott térség szempontjából legfontosabb területek ,ágazati fejlesztési koncepciójának" a funkcióját, legfeljebb megalapozhatja azokat: ez a megközelítési mozzanat következik egyfelöl a fentebbi három kitételből, továbbá a területi és ágazati aspektus elvi különbözőségéböl is; a jelenlegi körülmények között a területfejlesztési koncepció egyik meghatározó programja éppen egy adott terület ágazati fejlesztési koncepciójának kidolgozása lehet (miként a baranyai fejlesztési dokumentumban így szerepel például a megyei környezetvédelmi stratégia vagy a regionális közlekedésfejlesztési koncepció).

A koncepció tartalmát illetően két fejezetre tagolódott: a helyzetelemzésre és a fejlesztési koncepcióra. Mindkettő kidolgozásának a logikájában és formájában is az Európai Unió-beli tervezési normákhoz és követelményekhez igazodtunk.

\section{A Baranya megyei területfejlesztési koncepció tartalmi váza}

Bevezetés

I. Helyzetelemzés

1. Általános pozíció

2. A kistérségek rövid jellemzése

2.1. Pécsi kistérség - a kontrasztok térsége

2.2. Komlói kistérség - a szocialista városfejlesztés öröksége

2.3. Mohácsi kistérség - dinamikus agrárium, ősszetartó kőzösség

2.4. Pécsváradi kistérség - az önállósulás esélyei Pécs árnyékában

2.5. Sásdi kistérség - felzárkózás három megye határán

2.6. Sellyei kistérség - küzdelem a felemelkedésért

2.7. Siklósi kistérség - a kétarcú kistérség

2.8. Szigetvári kistérség - drámai hanyatlás, igéretesebb jövő

3. Összefoglaló helyzetértékelés (SWOT-elemzés)

II. Fejlesztési koncepció

1. Stratégiai célok

2. Fejlesztési célok (prioritások)

3. A fejlesztési célok programjainak kapcsolatai

3.1. A fejlesztési célok kapcsolatai a programokkal

3.2. A fejlesztési programok kistérségi kapcsolódásai

4. A végrehajtás mechanizmusa, szervezeti összefüggései

4.1. A dőntéshozás és a menedzsment-szervezés alapelvei

4.2. A tervezési, programozási folyamat

4.3. A területfejlesztési koncepció menedzsmentje

4.4. A fejlesztési koncepció teruleti információs rendszere, monitoringja

5. Ajánlás a területfejlesztési célelöirányzat decentralizált részének elosztási elveire

6. Javaslatok a kormányszervek döntési kompetenciájába tartozó feladatokra

A helyzetelemző rész - részletes állapotvizsgálatra támaszkodva - mind a megye egészérc, mind a kistérségckre lénycgében azonos szerkezetū, rendkívül koncentrált pozícióértékelést tartalmazott, továbbá összesített SWOT-elemzést. A fejlesztési koncepció rész a fejlesztési szlogen, a stratégiai célok, valamint a fejlesztési célok programjainak kapcsolataira, a végrehajtás mechanizmusára, szervezeti összefúggéseire vonatkozó részek, továbbá a területfejlesztési célelöirányzat decentralizált részének elosztási elveire történő ajánlás és a kormányszervek döntési 
kompetenciájába tartozó feladatokra szóló javaslatok mellett meghatározó részként a prioritások és programok bemutatását tartalmazza.

\section{Tanulságok}

Az újszerüség miatt számtalan tanulság adódott, amelyek közül a legáltalánosabbak az alábbiak:

- Az Európai Unióban bevett tervezési elvek és gyakorlat adaptálható a magyar intézményrendszerben, a szükséges tanulási folyamat idöigénye nem túl nagy. Kulcskérdés a megfelelő szakmai háttér (szervezet és személyzet) megteremtése mind a döntés-elökészitésben, mind a döntéshozatalban, mind pedig a monitoring és ellenőrzési rendszernél.

- Az alulról építkezés és a tervezés „társadalmasitása” munkaigényes, de nem nélkülözhető tervezési elv, a sikeres végrehajtás egyik garanciális eleme. Hangsúlyozni szükséges azonban, hogy a döntö mozzanat ennek során az egyeztetés, a különböző érdekek összevetése és a közös platform kialakitása, olykor kompromisszumok révén. Az alulról épitkezés nem kritikátlan ,gyüjtömunkát” jelent.

- A leggyengébb elem ma a partnerség-épités, minden jó szándékú hozzáállás ellenére. Jellemző, hogy a területfejlesztési koncepció megalkotása elsősorban a közigazgatási szféra szereplőire hárul, a gazdaság szereplöinek a részvétele kezdetleges. Az új, sokszereplős területfejlesztési rendszerünkben a jelenlegi, kialakulási fázisban - részben a régi reflexek müködése, részben a (saját) forrás hiánya miatt - még a (költségvetési) támogatás ösztönzi a helyi kezdeményezések megszületését, szemben a nyugat-európai gyakorlattal, ahol a meglevỏ és általában autonóm döntések formájában megjelenö helyi-vállalkozási-egyéni tervek közül választja ki a térségi tervezés a közösségi érdekeket leginkább szolgáló és ezért támogatandó vagy támogatható elemeket.

- Megfelelő döntés-elökészítéssel, az egyeztetések során megalapozott érveléssel kialakítható a különböző érdekeltségü szereplök tartós koncepcionális kompromisszuma, amely az alapelvek és normák torzulásmentes érvényesülése mellett jön létre. E nélkül a területfejlesztés hosszabb távú jellegéhez igazodó koncepcionális tartósság nem biztositható.

- A területfejlesztési tervezés modernizációja, az eurokonformitás megteremtése nem állhat meg a koncepció- vagy stratégiaépités szakaszában. A következő lépés a programozás elveinek és módszereinek az adaptálása, majd a Phare keretében kisérleti jelleggel már alkalmazott projekttervezés és üzleti terv készités általánossá tétele a területi tervezési folyamatban, a pályázati rendszerek igénybevételétől függetlenül is.

- Átgondolt tervezéssel már a jelen körülmények között is elkerülhetö az, hogy a koncepció egyszerüen a megyei forráselosztás eszköze legyen, sikeres cselekvési programnak kell lennie. Ha nem így lesz, akkor az egész irányítási és döntési rendszer elvileg szükséges és lassanként mindenki által elfogadott további decentralizációja elakadhat.

\section{Jegyzetek}

${ }^{1}$ Az elöadás $A$ területi tervezés új kihivása: a területfejlesztési koncepció c. konferencián hangzott el. (Györ, 1997. április 3-4.) 